\title{
Generational Socioemotional Wealth and Debt Maturity: Evidence from Private Family Firms of GIPSI Countries
}

\author{
Oscar Domenichelli ${ }^{1} \&$ Giulia Bettin ${ }^{2}$ \\ 1 Department of Management, Faculty of Economics "Giorgio Fuà", Università Politecnica delle Marche, \\ Ancona, Italy \\ ${ }^{2}$ Department of Economics and Social Sciences and Mo.Fi.R, Faculty of Economics "Giorgio Fuà", Università \\ Politecnica delle Marche, Ancona, Italy \\ Correspondence: Oscar Domenichelli, Department of Management, Faculty of Economics "Giorgio Fuà", \\ Università Politecnica delle Marche, Piazzale R. Martelli, 8, 60121, Ancona, Italy. Tel: 390-712-207-193.
}

Received: September 16, 2021

Accepted: October 26, 2021

Online Published: November 22, 2021

doi:10.5539/ijef.v13n12p67

URL: https://doi.org/10.5539/ijef.v13n12p67

\begin{abstract}
In this paper we investigate the relationship between generational socioemotional wealth (SEW) and debt maturity structure in private family firms of GIPSI countries for the period 2010-2018. This appears to be quite an important issue to study, given that SEW is a peculiar aspect of family firms and its impact on the debt maturity structure, still relatively unexplored, is likely to change according to the generation running the family business. We show that the importance attached to SEW decreases when moving from the firms' founder to the subsequent generations, with a negative effect on the amount of long-term debt. The forward-looking orientation of first-generation family firms favours long-term credit by banks in order to expand a healthy business which can be inherited by future generations. These businesses are hence perceived as less risky and more value-creating by external creditors, compared to later-generation family firms. Alternatively, SEW preservation is often less of a target in later-generation family firms, because some descendants consider the firm simply as a source of extra finance and conflicts of interest often arise between multiple generations or different family branches entering the business. Short-term debt may then be employed as a signaling effect of the quality of the firm. At the same time, borrowing long-term capital may become difficult if lenders question the creditworthiness of these businesses. This issue emerged dramatically during the sovereign debt crisis, when a significant contraction of credit to firms was observed throughout the GIPSI countries.
\end{abstract}

Keywords: private family firms, generational stage, debt maturity, socioemotional wealth, GIPSI countries

\section{Introduction}

In the last decades, an ample and growing body of empirical research has examined the importance of debt maturity structure, i.e., the combination of short- and long-term debt, by mainly considering agency conflicts, liquidity risk and asymmetric information (Barclay \& Smith, 1995; Stephan et al., 2011) (Note 1). While very many studies on debt maturity structure look at large companies all over the world (Barclay \& Smith, 1995; Guedes \& Opler, 1996; Stohs \& Mauer, 1996; Datta et al., 2005; Billett et al., 2007; Brockman et al., 2010; Antoniou et al., 2006; Ozkan, 2002; Chen et al., 1999), only a few investigations are conducted on small and medium-sized enterprises (e.g., Scherr \& Hulburt, 2001; Garcìa-Teruel \& Martinez-Solano, 2007; Lòpez-Gracia \& Mestre-Barberà, 2011) or private firms (Note 2) (Magri, 2010).

Debt maturity of family firms, in particular, has been little explored despite their relevance.

First, family firms are common worldwide (Klein, 2000; Morck \& Yeung, 2003; Astrachan \& Shanker, 2003). According to De Massis et al. (2018), citing the Family Firm Institute (2017), family businesses account for two-thirds of all businesses all over the world, generate around 70-90\% of annual global GDP and create 50-80\% of jobs worldwide. In the European Union, over $50 \%$ of enterprises are family held; in Latin America, family firms account for between $65 \%$ and $90 \%$ of enterprises; in the United States they represent more than $95 \%$ of businesses (PricewaterhouseCoopers, 2007); evidence on the importance of family firms has been provided also for Arab and MENA countries (Ayman et al., 2015).

Secondly, they constitute a very special kind of business relative to nonfamily ones. The so-called "familiness" 
(Habbershon \& Williams, 1999) of family firms implies a concentrated family ownership, a long investment horizon and the direct involvement of family members in managerial activities, with a specific generation guiding the firm (Cheng, 2014). Notwithstanding this uniqueness, there is not yet a widely accepted definition of family businesses (Barth et al., 2005; Amore et al., 2011; Anderson \& Reeb, 2003; Astrachan \& Shanker, 2003; Astrachan et al., 2002; Sharma, 2002; Villalonga \& Amit, 2010). While representing one of the challenges scholars face when they have to conceptualize a definition of family firm (Tsang, 2002), the presence of many classifications clearly implies that not all family firms are alike. In fact, important distinctions can be made among them, in terms of extent and mode of family involvement (Sharma, 2004), corporate governance and attention to socioemotional wealth (SEW) (Gómez-Mejia et al., 2007; Astrachan \& Jaskiewicz, 2008; Zellweger \& Astrachan, 2008; Berrone et al., 2010; 2012; Zellweger \& Dehlen, 2011; Cruz et al., 2012).

Studies on SEW follow the line of research based on behavioral theories (Araya-Castillo et al., 2021). According to these studies, SEW includes all non-financial aspects of the firm satisfying the family's affective needs (Sciascia et al., 2014). Creating SEW explains behavioural differences between family and non-family firms, and among family businesses across different generations, because SEW is a kind of resource that is difficult to imitate (Araya-Castillo et al., 2021) and characterizing the generational stage a family firm is going through. In fact, the relevance of SEW and its impact on the debt maturity structure of family businesses are likely to change on the basis of the generation running the family business (Gómez-Mejia et al., 2007). Specifically, SEW priorities, including family control and influence, family members' identification with the firm, binding social ties, emotional attachment, and renewal of family bonds to the firm through dynastic succession (Berrone et al., 2012) are expected to change throughout subsequent generations leading the family business (Le Breton-Miller \& Miller, 2013), as well as its debt maturity structure.

So far, the scant existing evidence on family firms' debt maturity is limited to Taiwanese listed companies (Shyu \& Lee, 2009), publicly listed Western Continental European firms (Croci et al., 2011), companies that are listed in the S\&P 1500 index (Chen et al., 2014), Italian firms (Domenichelli, 2015) and unlisted Spanish firms (Dìaz-Dìaz et al., 2016). Dìaz-Dìaz et al. (2016) show that in Spain private family firms have longer debt maturity compared to private non-family ones, indicating that family control mitigates agency conflicts between shareholders and creditors because of the family concern with managerial risk taking, long-term horizon and reputation, in line with previous literature (Anderson et al., 2003; Croci et al., 2011). Moreover, these results are also consistent with the conflict between majority and minority shareholders (Dìaz-Dìaz et al., 2016) and the need to safeguard and transfer a sound business on to later generations (Domenichelli, 2020).

However, in spite of the relevance of SEW and debt maturity structure in family firms, there is an evident gap in the existing studies which do not examine the linkages between the generation running a family firm and its SEW characteristics, and debt maturity structure. In fact, the SEW approach has so far mainly focussed on the following topics (Martínez-Romero \& Rojo-Ramirez, 2016): corporate responses to institutional pressures (Berrone et al., 2010) and their theoretical dimensions (Berrone et al., 2012); proactive stakeholder engagement (Cennamo et al., 2012); performance (Cruz et al., 2012; Detienne \& Chirico, 2013); earning management (Stockmans et al., 2010); organizational characteristics (Vandekerkhof et al., 2015) and effectiveness (Barros et al., 2017); subjective value perception (Zellweger \& Dehlen, 2011); intentions for transgenerational control (Zellweger et al., 2012).

When we look specifically at private family firms, the influence of the leading generation on SEW and thus on their debt maturity structure may prove to be very important. In fact, the tendency of private family firms to pursue SEW is not only influenced by family involvement and contribution (Chrisman et al., 2012), which is strong and characterized by solid family ownership and managerial concentration, but also by the absence of market oversight (Carney et al., 2015).

Therefore, this study develops and tests theoretical explanations for the heterogeneity observed in the debt maturity structure of private family firms by employing a generational perspective and its influence on SEW. The attachment to SEW of a private family firm depends on the features of the controlling family and we argue here that the generation leading a private family firm determines its inclination to SEW. Consequently, our research question can be stated as follows: How does the generation leading a private family business determine its SEW orientation and, in turn, its debt maturity structure?

The aim is to fill a gap in the understanding of the determinants of the debt maturity structure, by acknowledging the effect of the generational SEW on the debt maturity characteristics among private family firms of different generations.

We contribute to the scarce body of knowledge on the debt maturity of private family firms in two respects. First, 
we expand the knowledge of the role played by the generation leading family firms and its SEW attention in influencing their debt maturity structure.

Secondly, we enlarge the single country perspective taken in the most recent evidence on family firms (Domenichelli, 2015; Dìaz-Dìaz et al., 2016) by considering a sample of European firms drawn from the Amadeus database for the period 2010-2018. More specifically, we consider private family firms established in the GIPSI countries (Greece, Ireland, Portugal, Spain and Italy). In this way, we account for about $97 \%$ of the European private family firms covered in the Amadeus database and exclude all other countries for which the representativeness of the Amadeus sample of private family firms would be rather limited. In addition, the selected area represents a rather homogeneous sample in terms of institutional setting, given that four out of five countries share the French legal origin. At the same time, GIPSI countries were severely hit by the sovereign debt crisis that developed in the Euroarea just after the 2008 financial crisis, intensified by economic recession, public expenditure to rescue failing banks and poor fiscal management. An investigation of the debt maturity structure of family firms in these countries and its relationship with the SEW orientation of the generation leading the business may therefore offer interesting insights also on the consequences of the crisis.

The rest of the work is developed as follows. Section 2 reviews the related literature; provides our hypothesis concerning the relationship between SEW orientation of the generation running a family firm and its debt maturity expressed by long-term debt; and discusses further factors empirically influencing the choice of long-term debt. Section 3 describes the data and estimation model. Section 4 offers the results and interprets them. Section 5 concludes.

\section{Literature Review}

\subsection{SEW in (Private) Family Firms and the Structure of Their Debt Maturity}

Both family and nonfamily firms pursue financial and nonfinancial goals in their business activity (Zellweger et al., 2013). However, family firms pursue nonfinancial goals which uniquely reflect the interests, vision and attitude of the controlling family (Chrisman et al., 2012), which struggles to generate and preserve its SEW. There are several notions of SEW in the literature (Astrachan \& Jaskiewicz, 2008; Zellweger \& Astrachan, 2008; Berrone et al., 2010; Zellweger \& Dehlen, 2011; Berrone et al., 2012; Cruz et al., 2012). However, all these definitions follow the first development of the general SEW model (Berrone et al., 2012) by Gómez-Mejia et al. (2007). According to the latter, SEW is a group of several non-financial facets that includes identity, the exertion of family influence and dynastic perpetuation. Broadly speaking, SEW maintenance requires autonomy and control, family cohesiveness and supportiveness, loyalty, family name recognition, status and goodwill in the community (Zellweger et al., 2013). At the same time, it generates the need to pass the business on to future generations and to keep sustaining the family's image and reputation (Naldi et al., 2013).

SEW is also the primary reference point for private family firms (Stockmans et al., 2010). Prior studies assess the importance of SEW through the family's stock ownership (Hauck \& Prügl, 2015), which is nevertheless unlikely to capture the degree of orientation to SEW. In fact, we contend that the propensity to safeguard SEW varies along time (Gomez-Mejia et al., 2007; Martínez-Romero \& Rojo-Ramírez, 2016) according to the generation running the family firm. Hence, we consider the generation running a private family firm as the determinant of the importance given to SEW by a private family firm. In connection with this statement and building on the pivotal concept of Gomez-Mejia et al. (2007), we operationalize our definition of SEW in this way: SEW refers to the nonfinancial needs of a family firm, whose importance changes over time on the basis of the generation in charge of the family firm. Indeed, the attention attached to SEW - and to its various dimensions - differs across the subsequent generations of entrepreneurs (Berrone et al., 2012; Chua et al., 2012) that follow one another in the control of the business. The founder of a family firm pursues the primary objective of business success, through sustainability and growth, to ensure that it can survive and be passed on to later generations (Le Breton-Miller \& Miller, 2013). After the succession, some conflicts may arise between those family members who wish to expand the business and those who prefer generous dividends. However, at this phase of development of the family firm, emotional attachment, and the desire to maintain the control of the firm are likely to remain high (Le Breton-Miller \& Miller, 2013). The orientation to SEW becomes less relevant in later generational stages (Sciascia et al., 2014): when multiple generations take their place in the family business, further conflicts probably occur among different branches of the family (Stockmans et al., 2010), hence family social ties, attachment to the business and identification with it tend to weaken, so that for some family members the business is simply reduced to a source of financial support (Le Breton-Miller \& Miller, 2013).

On these premises, we contend that first-generation family firms use more long-term debt to enhance SEW development by pursuing a strategy of growth and sustainability of the business and strengthening the long-run 
control over the firm which can be passed on to future generations. At the same time, the long-term orientation along with the undiversified investments of the founding-family ownership lead these businesses to take sound and well-informed investment decisions. Therefore, founder-run firms are deemed to be less risky and more value-creating as opposed to later-generation family enterprises, and more likely to get long-term credit (Croci et al., 2011) that can be used to finance the long-term development of first-generation family businesses.

On the contrary, later generation family firms have a governance that becomes complicated, as these firms are older, larger, and more complex than those of the preceding generations (Le Breton-Miller \& Miller, 2013). Furthermore, attention to SEW weakens, because some descendants consider the firm simply as a source of extra finance, whereas conflicts of interest take place between multiple generations and between different family branches entering the business (Le Breton-Miller \& Miller, 2013). Consequently, later-generations family firms may need to shorten debt maturity to signal the firm's quality to creditors and their credible commitment to business health (Diamond, 1991). Indeed, frequent debt renewals would imply recurrent control by lenders and possibly a higher risk of financial distress as long as debts are not rolled over. This signaling effect is particularly strong in the case of private firms, since the discipline of the market for corporate control is absent (Straska \& Waller, 2014). Moreover, later-generation family firms could be perceived as lower-quality enterprises by potential lenders and not be able to raise long-term debt capital (Guedes \& Opler, 1996).

Hence the hypothesis we would like to test is the following: the probability of acquiring long-term debt decreases when the generation leading a family firm moves from the first to the subsequent ones.

\subsection{Other Determinants of Debt Maturity}

The corporate finance literature highlights other factors that can systematically affect the choice of the debt maturity (Dìaz-Dìaz et al., 2016), such as those related to agency conflicts between shareholders and creditors (Myers, 1977; Barnea et al., 1980), financial flexibility (DeAngelo, H. \& DeAngelo, L., 2007), trade-off theory (Kraus \& Litzenberger, 1973; Rajan \& Zingales, 1995), pecking order theory (Myers, 1984; Myers \& Majluf, 1984), maturity matching (Morris, 1976; Stohs \& Mauer, 1996), taxation (Brick \& Ravid, 1985; Lewis, 1990; Brick \& Ravid, 1991), and asymmetric information (Flannery, 1986; Diamond, 1991; Kale \& Noe, 1990).

Barnea et al. (1980) contend that the use of short-term debt may lead to the solution of both the over-investment and the under-investment problems in the context of agency conflicts between shareholders and lenders. These conflicts increase when firms have significant growth opportunities, as large debt capital is demanded to finance the development of the firm. Several studies provide evidence of a negative relationship between growth opportunities and debt maturity (Barclay \& Smith, 1995; Chen et al., 1999; Stephan et al., 2011). However, Villalonga et al. (2015) argue that the conflicts of interests between shareholders and creditors tend to be less severe in family firms compared to non-family ones. According to Anderson et al. (2003), family shareholders want to ensure the long-term survival of the firm and to preserve the family's reputation. Besides, their investments are also undiversified. These specificities usually encourage family businesses to maximize the overall firm value, rather than simply focus on shareholder value, and establish fair and long-lasting relationships with their lenders. Therefore, family businesses with considerable investments in intangible assets (such as patents, trademarks, brand recognition, etc.) - i.e., significant growth opportunities - can borrow long-term debt to appropriately finance them. In addition, as intangible assets are usually long-term investments, according to the maturity matching principle a positive relationship between growth opportunities and the debt maturity is expected. Hence the higher the growth opportunities, the higher the proportion of long-term debt.

Financial flexibility concerns the ability of a firm to easily employ financial resources to invest in its projects when it needs to. Low leveraged and more liquid firms are better equipped to support their development. According to DeAngelo, H. and DeAngelo, L. (2007), today's borrowing cost can be also interpreted as the opportunity cost of giving up any chance to borrow in the near future. To the extent that low current debt creates conditions for future expansion (Ferrão et al., 2016), firms will prefer to have low leverage today to preserve their debt capacity for financing forthcoming investment opportunities (Dang, 2013). Hence, high indebted firms exhaust this capacity and face difficulties in raising long-term debt capital to finance their development. Furthermore, liquidity makes firms more financially flexible, because a readily available reserve of financial resources can be used to develop new strategies (Burgeois, 1981) and maintain tomorrow's long-term debt accessibility for future investments. As a result, the higher the leverage and liquidity of a (family) firm, the lower the incidence of its long-term debt.

When we look at the trade-off theory (Kraus \& Litzenberger, 1973; Rajan \& Zingales, 1995), larger firms face lower bankruptcy costs as they have reduced levels of asymmetric information (Dìaz-Dìaz et al., 2016), are more diversified, generate more steady profits, and cash flows (Rajan \& Zingales, 1995; D’Amato, 2020), thus they 
can easily postpone their debt maturity. Furthermore, both considerable fixed assets - which imply lower bankruptcy costs - and taxation - that is the benefit of the tax shield - generate propensity towards increasing long-term debt.

However, according to the pecking order theory (Myers, 1984; Myers \& Majluf, 1984), retained profits allow private (family) firms to expand in the long run without resorting to long-term debt. In fact, larger private (family) businesses and firms with more fixed assets can benefit from internally generated earnings that are ploughed back into the firm's development. Therefore, based on the pecking order approach, size, fixed assets, and profitability are negatively related to long-term debt.

The trade-off approach also predicts that when there are non-debt tax-shields, such as depreciation and amortization, a firm can reduce its tax burden (DeAngelo \& Masulis, 1980) with lower long-term debt employment. Thus, a negative relationship is also expected between long-term debt and non-debt tax shields. On the contrary, higher taxation implies higher tax-shields and greater use of long-term debt.

\section{Methods}

\subsection{Sample Definition}

The sample of our analysis includes unlisted European family firms drawn from Amadeus, for the period 2010-2018. Amadeus is a database collected by Bureau van Dijk, which delivers detailed information from balance sheets and income statements for public and private companies based in 43 countries, covering all sectors of activity. Following previous studies (Anderson \& Reeb, 2003, Anderson et al., 2003; Barth et al., 2005; Amore et al., 2011; Croci et al., 2011; Dìaz-Dìaz et al., 2016), we take ownership as the criterion for defining family firms. Specifically, private family firms are defined as unlisted firms in which one or more named individuals or families jointly own at least $50 \%$ of the equity. Given that privately-held firms mostly have concentrated ownership structures, such a threshold is needed to attain control (Amore et al., 2011) and power to select the members of the board of directors and influence the strategic choices of a private family firm through the degree of attention to SEW. The initial sample consists of all active unlisted (or private) non-financial family firms, of which we keep only those with at least 10 employees and a turnover greater than 2 million euros, so as to guarantee greater comparability with most of the studies on family firms, that deal with relatively large companies (Lòpez-Gracia \& Sànchez-Andùliar, 2007). We then remove firms with missing observations or negative values for equities, current assets, current liabilities, tangible fixed assets, investments and effective tax rates. Finally, all variables showing extreme values have been winsorized at the upper and lower $1 \%$.

The final sample includes 9,068 private family firms for the period between 2010 and 2018 from 5 European countries. As a matter of fact, we focus on the GIPSI (Greece, Ireland, Portugal, Spain and Italy) countries in our analysis. This choice has two main motivations. First, we account for a very high share (about 97\%) of European private family firms covered in the Amadeus database and exclude all countries for which the representativeness of the Amadeus sample of family firms would be rather limited. Second, in terms of institutional characteristics we consider a rather homogeneous sample, given that four out of five countries share their French legal origin. This allows us to improve on literature, which focussed mainly on country case studies, but at the same time we are confident that we are looking at firms operating in similar institutional settings. In other words, our results regarding the debt maturity structure of private family firms should not be driven by the cross-country differences in the legal and institutional framework we could be hardly controlling for in a fixed-effects setting like the one applied below. Finally, GIPSI countries were severely hit by the sovereign debt crisis that developed in the Euroarea just after the 2008 financial crisis, induced by economic recession, public expenditure to rescue failing banks and poor fiscal management. An examination of the debt maturity structure of family businesses in these countries, its relationship with generational SEW and with other potential determinants may therefore provide solid evidence also on the consequences of the crisis.

\subsection{Model Characteristics}

We employ the following empirical specification:

$$
\text { Debt Maturity }{ }_{i, j, t}=\alpha+\beta G_{i, t}+\gamma X_{i, t}+\tau_{t}+\varphi_{s}+\varepsilon_{i, t}
$$

where Debt Maturity $\mathrm{i}_{\mathrm{i}, \mathrm{r}}$ represents long-term debt over total assets for firm i in country $\mathrm{j}$ at time t. $\mathrm{G}_{\mathrm{i}, \mathrm{t}}$ represents a set of four dummy variables that refer to the generation leading firm $i$ at time $t$. $X_{i, t}$ is a matrix of firm-level characteristics. $\tau_{\mathrm{t}}$ and $\varphi_{\mathrm{s}}$ are respectively time and country dummy variables, while $\varepsilon_{\mathrm{i}, \mathrm{t}}$ represents the idiosyncratic error term.

For our estimates, we employ a Fixed Effect (FE) estimator to test the main hypothesis discussed in Section 2. By controlling for unobserved individual heterogeneity, the FE estimator allows for attenuating potential 
endogeneity issues related to our right-hand side variables.

\subsection{Regression Variables}

The definition and source for each variable are reported in Table 1, and further described below.

Table 1. Variables' definition and source

\begin{tabular}{lll}
\hline Variable & Definition & Source \\
\hline debt maturity & long-term debt (non-current liabilities)/ total assets & Amadeus \\
first generation & dummy equal to 1 if less than 25 years have passed since the incorporation; 0 otherwise & Amadeus \\
second generation & dummy equal to 1 if $25>=$ years since the incorporation $>50 ; 0$ otherwise & Amadeus \\
third generation & dummy equal to 1 if $50>=$ years since the incorporation $>75 ; 0$ otherwise & Amadeus \\
further generations & dummy equal to 1 if 75 or more years have passed since the incorporation; 0 otherwise & Amadeus \\
growth & intangible fixed assets/total assets & Amadeus \\
profitability & earnings before interest, tax, depreciation, and amortization (EBITDA) / total assets & Amadeus \\
fixed assets & fixed assets/ total assets & Amadeus \\
liquidity & (stock + debtors + other current assets)/ current liabilities & Amadeus \\
leverage & (non-current liabilities + current liabilities)/total assets & Amadeus \\
size & natural logarithm of total assets & Amadeus \\
non-debt tax shields & depreciation and amortization / total assets & Amadeus \\
taxation & taxation/ earnings before tax & Amadeus \\
\hline
\end{tabular}

The dependent variable is debt maturity. Alternative definitions of short- and long-term debt are available in the international literature (Antoniou et al., 2006). Debt can be considered long-term if it is payable after a year (Scherr \& Hulburt, 2001) or after three years (Barclay \& Smith, 1995). A weighted average maturity of liabilities can also be employed (Stohs \& Mauer, 1996; Scherr \& Hulburt, 2001). Firms have many different contractual obligations, such as bank debts, loans from related companies, trade debts (Kirch \& Terra, 2012) and bonds, as well as legal and tax obligations, composing their debt maturity. Thus, our measure of debt maturity takes into account all debt, debtlike obligations and current liabilities (Stohs \& Mauer, 1996). Extending the reasoning of Stohs \& Mauer (1996), all these liabilities represent obligations a firm must satisfy. Furthermore, their employment allows a firm to finance its investments, as a whole. Consequently, it is important to consider all types of liabilities of a firm, when interpreting the underlying reasons for its debt maturity choices. In line with Croci et al. (2011), we express debt maturity as the ratio of long-term liabilities over total assets.

The main hypothesis we want to test with our model is the effect of the different generations leading the family firm and their attachment to SEW on the debt maturity structure of the firm. We therefore define first generation as a dummy variable equal to 1 if the first generation of a family is likely to lead it, that is if less than 25 years have passed since the incorporation, and 0 otherwise. Second generation takes value 1 if the age of the firms is between 25 and 50 years and 0 otherwise. Third generation is equal to 1 if the age of the firm is between 50 and 75 years and 0 otherwise. Finally, further generations takes value 1 for those firms whose age is greater than 75 years and 0 otherwise. Our model includes the first three dummies, being the latter our reference category.

The selection of control variables is based on the existing literature, as discussed in Section 2. We include growth expressed as the ratio of intangible fixed assets to total assets in order to proxy for firms' growth opportunities. At the same time, we also control for firms' profitability, measured as the ratio between earnings before interest, tax, depreciation, and amortization (EBITDA) and total assets. Following the reasoning in D'Amato (2020), this measure is considered more appropriate than indexes such as ROI or ROE because it is less subject to accounting manipulations related to the evaluation of amortization and/or depreciation. An additional control is the fixed assets, calculated as the ratio between fixed and total assets (Daskalakis et al., 2017; Daskalakis \& Psillaki, 2008; López-Gracia \& Sogorb-Mira, 2008). Liquidity is measured by the ratio of current assets to current liabilities (D'Amato, 2020), whereas to measure the indebtedness we use Leverage, calculated as the ratio of total liabilities to total assets. The dimension of a firm is accounted for by including firms' size, that is the natural logarithm of total assets.

Non-debt tax shields expressed as the ratio of total depreciation and amortization expenses to total assets (Titman \& Wessels, 1988) captures the possibility of using alternative tax shields - as opposed to debt interest - to reduce the tax burden of a firm.

Lastly, we control also for the importance of taxation, measured as the ratio of taxes paid to earnings before tax. 


\section{Results and Discussion}

\subsection{Descriptive Statistics}

Descriptive statistics on our sample of private family firms are reported in Table 2 and the main results are commented upon below.

Table 2. Descriptive statistics

\begin{tabular}{lccccc}
\hline & Obs & Mean & Std. Dev. & Min & Max \\
\hline debt maturity & 75,799 & 0.11 & 0.11 & 0.00 & 0.52 \\
first generation & 75,799 & 0.44 & 0.50 & 0.00 & 1.00 \\
second generation & 75,799 & 0.49 & 0.50 & 0.00 & 1.00 \\
third generation & 75,799 & 0.06 & 0.23 & 0.00 & 1.00 \\
further generations & 75,799 & 0.01 & 0.09 & 0.00 & 1.00 \\
growth & 75,798 & 0.02 & 0.04 & 0.00 & 0.21 \\
profitability & 75,503 & 0.08 & 0.06 & -0.01 & 0.30 \\
fixed assets & 75,799 & 0.31 & 0.21 & 0.01 & 0.94 \\
liquidity & 75,794 & 1.59 & 1.01 & 0.37 & 7.25 \\
leverage & 75,799 & 0.27 & 0.17 & 0.00 & 0.68 \\
size & 75,799 & 9.45 & 0.82 & 7.44 & 11.63 \\
non-debt tax shields & 75,513 & 0.03 & 0.02 & 0.00 & 0.11 \\
taxation & 75,321 & 0.41 & 0.52 & -1.86 & 3.27 \\
\hline
\end{tabular}

First of all, liquidity, size, taxation, first and second generation have the highest variability as their standard deviation is large compared to their sample average. By contrast, non-debt tax shields, further generation, profitability, and growth display the lowest variability.

In greater detail, the average share of long-term debt over total assets is equal to $11 \%$ in our estimation sample, with a maximum value of $52 \%$. In terms of generation, first- and second-generation family firms account for the vast majority of our sample. Specifcally, $44 \%$ of family firms are likely to be directly led by the founder and $49 \%$ by her/his direct descendants (second generation). The third generation of heirs represents only $6 \%$ of firms in our sample whereas the fourth or further generations are the remaining $1 \%$.

The average profitability is equal to 0.08 , while the minimum level is -0.01 . This documents an overall ability of the firms being studied to generate value, although the period of the investigation (2010-2018) substantially covers the international financial crisis of sovereign debt, which has severely affected the GIPSI countries. On average, the value for fixed assets is 0.31 and shows that current assets represent by far the main form of investment among private family enterprises. The mean value for leverage is 0.27 and that highlights a low capability of indebtedness of private family firms when comparing with their listed counterparts, as private firms are opaquer and have no access to bond issues on financial markets (Domenichelli, 2020). Finally, whereas the average value for liquidity, that is 1.59 , shows a significant business ability to repay current liabilities by using current assets, including available cash, average taxation (0.41) implies a considerable tax burden for the private family firms being analysed.

\subsection{Estimation Results}

The results of the regression are shown in Table 3. Column 1 refers to a baseline specification where no control variables are included whereas column 2 shows results for our complete specification as described in Section 4. The panel of firms is unbalanced and made up of all firms that are included in the Amadeus database for at least two consecutive years. We have 9,068 firms (75,799 observations) in the baseline specification without any control variable, and 9,051 firms (75,075 observations) in the specification where additional determinants of long-term debt are controlled for. 
Table 3. Estimation results

\begin{tabular}{|c|c|c|c|}
\hline & 1 & 2 & 3 \\
\hline \multirow[t]{2}{*}{ first generation } & $0.021 *$ & $0.021 * *$ & $0.020^{*}$ \\
\hline & {$[0.012]$} & {$[0.010]$} & {$[0.011]$} \\
\hline \multirow[t]{2}{*}{ second generation } & $0.022^{*}$ & $0.021 * *$ & $0.020^{*}$ \\
\hline & {$[0.012]$} & {$[0.010]$} & {$[0.011]$} \\
\hline \multirow[t]{2}{*}{ third generation } & 0.019 & $0.017 *$ & 0.016 \\
\hline & {$[0.012]$} & {$[0.009]$} & {$[0.010]$} \\
\hline \multirow[t]{2}{*}{ growth } & & $0.077 * * *$ & $0.085^{* * *}$ \\
\hline & & {$[0.022]$} & {$[0.026]$} \\
\hline \multirow[t]{2}{*}{ profitability } & & $-0.030 * * *$ & $-0.021 * *$ \\
\hline & & [0.010] & {$[0.011]$} \\
\hline \multirow[t]{2}{*}{ fixed assets } & & $-0.103^{* * *}$ & $-0.108 * * *$ \\
\hline & & [0.006] & [0.007] \\
\hline \multirow[t]{2}{*}{ leverage } & & $-0.160 * * *$ & $-0.162 * * *$ \\
\hline & & [0.006] & [0.007] \\
\hline \multirow[t]{2}{*}{ liquidity } & & $-0.008 * * *$ & $-0.009 * * *$ \\
\hline & & {$[0.001]$} & {$[0.001]$} \\
\hline \multirow[t]{2}{*}{ size } & & $-0.006^{* * *}$ & $-0.008 * * *$ \\
\hline & & {$[0.002]$} & [0.002] \\
\hline \multirow[t]{2}{*}{ non-debt tax shields } & & $-0.103 * * *$ & $-0.118 * * *$ \\
\hline & & [0.036] & {$[0.040]$} \\
\hline \multirow[t]{2}{*}{ taxation } & & 0.001 & 0.001 \\
\hline & & {$[0.000]$} & {$[0.001]$} \\
\hline Year FE & yes & yes & yes \\
\hline Country*Year FE & yes & yes & yes \\
\hline Observations & 75,799 & 75,075 & 58,191 \\
\hline Number of firms & 9,068 & 9,051 & 6,509 \\
\hline
\end{tabular}

Note. The table reports regression coefficients and its significance level. * significant at $10 \%$; ** significant at $5 \%$; $* * *$ significant at $1 \%$. Standard errors are clustered at the firm level. Estimations are carried out by using a panel fixed-effects estimator. The dependent variable is expressed as non-current liabilities/ total assests.

The main hypothesis we would like to test with our empirical exercise is that the share of long-term debt decreases as we move from the first generation of entrepreneurs to the subsequent ones. The coefficient of first generation is positive and statistically significant, as well as the one on second generation. This means that compared to the reference category (fourth generation and further), both family firms that are likely to be led by the founder and her/his direct descendants show a higher incidence of long-term debt compared to firms of the fourth generation or subsequent ones. The coefficient on third generation is again positive but statistically significant only when considering the full specification that includes all control variables in column 2 . This may hint at the fact that the importance of SEW decreases over time and hence differences in the impact on long-term debt become weaker when comparing family firms of the third generation and the subsequent ones. This is confirmed also by the size of the coefficients, which is substantially the same for first generation and second generation and gets smaller in the case of third generation. Therefore, the hypothesis we tested according to which the probability of acquiring long-term debt decreases when the generation leading a family business moves from the first to the subsequent ones is completely confirmed.

In order to fully understand such results, it is worth highlighting that firms' creditworthiness was a crucial issue in the crisis years, especially in the first period when largely expansive monetary policies had not yet been implemented by the European Central Bank and credit crunch and credit rationing phenomena were largely observed across Europe, mostly in GIPSI countries (see, among others, Barone et al., 2018 and Bofondi et al., 2018 for Italy; Carbó Valverde et al., 2012 and Hernando \& Villanueva, 2014 for Spain). These countries indeed experienced a vicious circle, or doom loop (Farhi \& Tirole, 2018), that linked together sovereign debt crisis, bank fragility and economic recession.

Specifically, banks faced severe financial consequences. First, they were exposed to sovereign debt, whose price sharply decreased. That caused a reduction in the value of the equity of banks which became less financially 
solid, especially in light of the new and more stringent capital requirements introduced by the Basel III rules regulatory framework. As a result, banks found it more difficult to collect resources from depositors, corporate bond issues or other banks (at least at affordable costs) to grant new credit to the economy. The loan supply was also deteriorated by the rising share of banks' liquidity invested in sovereign debt (Acharya et al., 2018) and by the increasing amount of non-performing loans (Corbisiero \& Faccia, 2020). Finally, the actual access to credit by businesses decreased owing to the tightening credit conditions, and in particular because of the significant rise in lending interest rates which somehow had to compensate for the general weakening of firms' creditworthiness (Demirgüç-Kunt et al., 2020).

These factors and their interplay led to a significant contraction of credit to (family) firms, but in this context first-generation private family firms could take advantage of the role of SEW compared to private family firms run by further generations, which probably experienced higher risk of credit rationing or refusal by banks and had therefore greater difficulties in accessing long-term debt.

The coefficient for growth is positive and highly significant and this confirms strong alignment of interests between owners and creditors, thanks to long-term SEW objectives of private family firms, such as the continuation of the business, preservation of family's ownership and reputation, and safeguard of the considerable investments of family owners. These results are therefore in line with the evidence of both Dìaz-Dìaz et al. (2016), who contend that there are lower agency conflicts between shareholders and creditors in private family firms, and Croci et al. (2011) who claim the incentive to avoid risky investments is higher for family shareholders who have their wealth mostly invested in the firm. This mitigates owner-lender agency conflicts and makes long-term debt easier to raise. Hence, unlisted family firms do not need short-term debt to minimize owner-lender conflicts of interest. If fixed intangible investments increase - i.e., growth opportunities rise -, they will be easily financed by long-term debt.

As contended, higher leverage and greater liquidity imply lower use of long-term debt, because the coefficients for leverage and liquidity are both negative and very significant. This means that high leveraged private family firms find it difficult to gather long-term debt for new investment opportunities, because of their riskiness. At the same time, considerable liquidity avoids long-term debt use to finance the growth of private family businesses and allow them to keep spare indebtedness capacity.

The pecking order approach is deemed to be followed by private family firms as more profitable private family businesses have stronger possibility of reinvesting earnings to increase their size and fixed assets with no use of large amount of long-term debt. This is confirmed by the highly negative and statistically significant coefficients for profitability, size, and fixed assets.

Taxation hardly exerts any effect on the debt maturity structure. This result is consistent with other studies, which provide no evidence of a significant connection between the two variables (Barclay \& Smith, 1995; Guedes \& Opler; 1996; Ozkan, 2000). On the contrary, the coefficient for non-debt tax shields is negative and statistically significant since the stronger the presence of alternative tax shields, the lower the use of interest on long-term debt to decrease business taxation.

\subsection{Robusteness Checks: Balanced Panel Estimation}

In order to verify the robustness of our results, we limit the analysis to a balanced panel of firms that were included in the Amadeus database for the entire period at our disposal. In this way, the number of firms decreases to 6,509 , with 58,191 observations. Results are reported in Table 3, column 3 . The evidence provided by the main specification presented in column 2 is broadly confirmed: all the main drivers of debt maturity discussed in the previous section are still significant and maintain the same sign. The only appreciable difference is related to the dummy variable for the third generation, which is still positive but not significant anymore. As already pointed out in the previous section when discussing results in column 1, this seems to suggest that differences across generations in the debt maturity structure become weaker when comparing family firms led by the third generation and the subsequent ones with respect to first and second generations.

\section{Conclusions}

Our study on the relationship between generational SEW and long-term use of debt in private family firms belonging to GIPSI countries highlights the following results.

The amount of long-term debt decreases as we move from the first generations of entrepreneurs to the next ones. Hence our hypothesis is confirmed: the importance attached to SEW and its impact on long-term debt employment change over time. First-generation family firms need to enhance their SEW, consequently they develop a strategy of growth and sustainability of the enterprise and strengthen the control over the business. In 
doing so, the founder makes large use of long-term indebtedness to ensure the development of a healthy business which can be inherited by future generations. Besides, both the long-term orientation and the undiversified investments of the founding-family ownership make creditors willing to lend money to first-generation family businesses on a long-term basis, since these firms are perceived as less risky and more value-creating, relative to later-generation family firms. Later-generation family firms are less involved on the preservation of SEW, as some descendants tend to see the firm as a source of extra finance. At the same time, conflicts of interest occur between multiple generations and between different branches of cousins entering the business, while the governance of these family firms, older, larger and complex, becomes complicated. As a result, the long-term share is lower in later-generation family firms, because, on the one hand, they tend to signal the viability and quality of the business by decreasing their debt maturity and, on the other, as lenders perceive these businesses as being of lower quality, the latter could not be able to borrow long-term capital. Firms' creditworthiness was a crucial issue during the sovereign debt crisis, when a significant contraction of credit to firms was observed throughout the GIPSI countries. Within such a scenario, first-generation private family firms could take advantage of the role played by SEW and therefore face lower difficulties in accessing long-term credit from banks compared to private family firms run by succeeding generations.

Furthermore, the analysis of other determinants of debt maturity shows that negligeable agency conflicts between shareholders and lenders in private family firms does not prevent them from acquiring long-term debt to finance growth opportunities and to match long-term sources of finance with long-term assets. A higher leverage of private family firms means a stronger risk and lesser ability to fund new investments through the use of long-term debt, whereas greater liquidity implies a lower need for long-term debt, as these businesses can count on more readily available cash. The pecking order model is also justified because greater profitability, size, and fixed assets show higher availability of earnings which have been reinvested, thus reducing the use of long-term debt. Finally, the trade-off approach is confirmed when we look at the role of non-debt tax shields.

This work has limitations that can provide future lines of research. The relationship between generational SEW and debt maturity could be further explored in a wider cross-country setting, by considering a larger and more heterogeneous sample of countries. This extension would then require taking into account also country-level differences in terms of institutional quality, government effectiveness and size, and efficiency of the financial sector. Being most of these aspects strongly persistent over time, the challenge would also be methodological, as fixed effects settings, such as the one used in this paper, could not apply. In addition, longer panels of firms would allow for a better understanding of the relationship over time, thus allowing a deeper comprehension of the peculiarities of older firms run by the third generation, or even further ones. At the same time, a longer time coverage after the crises that severely hit the European economy in the last decade would help in comparing the role of SEW in affecting firms' debt maturity structure in crisis versus non crisis periods.

\section{Acknowledgments}

We are grateful to Viet Anh Dang, Amedeo De Cesari, Arif Khurshed and Konstantinos Stathopoulos for their helpful comments and suggestions on a very preliminary version of this work. All remaining errors are ours.

\section{References}

Acharya, V. V., Eisert,T., Eufinger, C., \& Hirsch, C. (2018). Real Effects of the Sovereign Debt Crisis in Europe: Evidence from Syndicated Loans. The Review of Financial Studies, 31(8), 2855-2896. https://doi.org/10.1093/rfs/hhy045

Amore, M. D., Minichilli, A., \& Corbetta, G. (2011). How do managerial successions shape corporate financial policies in family firms? Journal of Corporate Finance, 17(4), 1016-1027. https://doi.org/10.1016/j.jcorpfin.2011.05.002

Anderson, R. C., \& Reeb, D. M. (2003). Founding-Family Ownership and Firm Performance: Evidence from the S\&P 500. Journal of Finance, 58(3), 1301-1328. https://doi.org/10.1111/1540-6261.00567

Anderson, R. C., Mansi, S. A., \& Reeb, D. M. (2003). Founding family ownership and the agency cost of debt. Journal of Financial Economics, 68(2), 263-285. https://doi.org/10.1016/S0304-405X(03)00067-9

Antoniou, A., Guney, Y., \& Paudyal, K. (2006). The Determinants of Debt Maturity Structure: Evidence from France, Germany and the UK. European Financial Management, 12(2), 161-194. https://doi.org/10.1111/j.1354-7798.2006.00315.x

Araya-Castillo, L., Hernández-Perlines F., Moraga, H., \& Ariza-Montes, A. (2021). Scientometric Analysis of Research on Socioemotional Wealth. Sustainability, 13(3742), 1-26. https://doi.org/10.3390/su13073742 
Astrachan, J. H., \& Jaskiewicz, P. (2008). Emotional Returns and Emotional Costs in Privately Held Family Businesses: Advancing Traditional Business Valuation. Family Business Review, 21(2), 139-149. https://doi.org/10.1111/j.1741-6248.2008.00115.x

Astrachan, J. H., \& Shanker, M. C. (2003). Family Businesses' Contribution to the U.S. Economy: A Closer Look. Family Business Review, 16(3), 211-219. https://doi.org/10.1177/08944865030160030601

Astrachan, J. H., Klein, S. B., \& Smyrnios, K. X. (2002). The F-PEC Scale of Family Influence: A Proposal for Solving the Family Business Definition Problem. Family Business Review, 15(1), 45-58. https://doi.org/10.1111/j.1741-6248.2002.00045.x

Ayman, E. H., AlShattarat, W. K., AbuGhazaleh, N. M., \& Nobanee, H. (2015). The Impact of Ownership Structure and Family Board Domination on Voluntary Disclosure for Jordanian Listed Companies. Eurasian Business Review, 5(2), 203-234. https://doi.org/10.1007/s40821-015-0021-5

Barclay, M. J., \& Smith, C. W. Jr. (1995). The Maturity Structure of Corporate Debt. Journal of Finance, 50(2), 609-631. https://doi.org/10.1111/j.1540-6261.1995.tb04797.x

Barnea, A., Haugen, R. A., \& Senbet, L. W. (1980). A rationale for debt maturity structure and call provisions in the agency theory framework. Journal of Finance, 35(5), 1223-1234. https://doi.org/10.1111/j.1540-6261.1980.tb02205.x

Barone, G., de Blasio, G., \& Mocetti, S. (2018). The real effects of credit crunch in the great recession: Evidence from Italian provinces. Regional Science and Urban Economics, 70(C), 352-359. https://doi.org/10.1016/j.regsciurbeco.2017.10.003

Barros, I., Hernangómez, J., \& Martin-Cruz, N. (2017). Familiness and socioemotional wealth in Spanish family firms: An empirical examination. European Journal of Family Business, 7(1-2), 14-24. https://doi.org/10.24310/ejfbejfb.v7i1-2.5014

Barth, E., Gulbrandsen, T., \& Schøne, P. (2005). Family ownership and productivity: The role of $\begin{array}{lllll}\text { owner-management. Journal of Corporate } & \text { Finance, 11(1), 107-127. }\end{array}$ https://doi.org/10.1016/j.jcorpfin.2004.02.001

Berrone, P., Cruz, C., \& Gomez-Mejia, L. R. (2012). Socioemotional Wealth in Family Firms: Theoretical Dimensions, Assessment Approaches, and Agenda for Future Research. Family Business Review, 25(3), 258-279. https://doi.org/10.1177/0894486511435355

Berrone, P., Cruz, C., Gomez-Mejia, L. R., \& Larraza-Kintana, M. (2010). Socioemotional Wealth and Corporate Responses to Institutional Pressures: Do Family-Controlled Firms Pollute Less? Administrative Science Quarterly, 55(1), 82-113. https://doi.org/10.2189/asqu.2010.55.1.82

Billett, M. T., King, T. H. D., \& Mauer, D. C. (2007). Growth Opportunities and the Choice of Leverage, Debt $\begin{array}{lllll}\text { Maturity, and Covenants. Journal of } & \text { Finance, 62(2), }\end{array}$ https://doi.org/10.1111/j.1540-6261.2007.01221.x

Bofondi, M., Carpinelli, L., \& Sette, E. (2018). Credit Supply During a Sovereign Debt Crisis. Journal of the European Economic Association, 16(3), 696-729. https://doi.org/10.1093/jeea/jvx020

Bourgeois, III L. J. (1981). On the measurement of organizational slack. Academy of Management Review, 6(1), 29-39. https://doi.org/10.2307/257138

Brick, I. E., \& Ravid, S. A. (1991). Interest rate uncertainty and the optimal debt maturity structure. Journal of Financial and Quantitative Analysis, 26(1), 63-81. https://doi.org/10.2307/2331243

Brick, I., \& Ravid, A. (1985). On the relevance of debt maturity structure. Journal of Finance, 40(5), 1423-1437. https://doi.org/10.1111/j.1540-6261.1985.tb02392.x

Brockman, P., Martin, X., \& Unlu E. (2010). Executive Compensation and the Maturity Structure of Corporate Debt. Journal of Finance, 65(3), 1123-1161. https://doi.org/10.1111/j.1540-6261.2010.01563.x

Carbó, V. S., Degryse, H., \& Rodriguez-Fernandez, F. (2012). Lending relationships and credit rationing: The impact of securitization. CEPR Discussion Papers 9138, Centre for Economic Policy Research. Retrieved from https://cepr.org/active/publications/discussion_papers/dp.php?dpno=9138

Carney, M., Van Essen, Gedajlovic, E. R., \& Heugens, P. P. M. A. R (2015). What Do We Know About Private Family Firms? A Meta-Analytical Review. Entrepreneurship Theory and Practice, 39(3), 513-544. https://doi.org/10.1111/etap.12054 
Cennamo, C., Berrone, P., Cruz, C., \& Gomez-Mejia, L. R. (2012). Socioemotional Wealth and proactive stakeholder engagement: Why family-controlled firms care more about their stakeholders. Entrepreneurship Theory and Practice, 36(6), 1153-1173. https://doi.org/10.1111/j.1540-6520.2012.00543.x

Chen, S. S., Ho, K. W., \& Yeo, G. H. (1999). The Determinants of Debt Maturity: The Case of Bank Financing in Singapore. Review of Quantitative Finance and Accounting, 12(4), 341-350. https://doi.org/10.1023/A:1008398308408

Chen, T. Y., Dasgupta, S., \& Yu, Y. (2014). Transparency and Financing Choices of Family Firms. Journal of Financial and Quantitative Analysis, 49(2), 381-408. https://doi.org/10.1017/S0022109014000313

Cheng, Q. (2014). Family firm research - A review. China Journal of Accounting Research, 7(3), 149-163. https://doi.org/10.1016/j.cjar.2014.03.002

Chrisman, J. J., Chua, J. H., Pearson, A. W., \& Barnett, T. (2012). Family Involvement, Family Influence, and Family-Centered Non-Economic Goals in Small Firms. Entrepreneurship Theory and Practice, 36(2), 267-293. https://doi.org/10.1111/j.1540-6520.2010.00407.x

Chua, J. H., Chrisman, J. J., Steier, L. P., \& Rau, S. B (2012). Sources of Heterogeneity in Family Firms: An Introduction. Entrepreneurship Theory and Practice, 36(6), 1103-1113. https://doi.org/10.1111/j.1540-6520.2012.00540.x

Corbisiero, G., \& Faccia, D. (2020). Firm or bank weakness? Access to finance since the European sovereign debt crisis. Working papers, European Central Bank, Number 2361, 1-44. Retrieved from https://www.ecb.europa.eu/pub/pdf/scpwps/ecb.wp2361 5cb34f67a7.en.pdf

Croci, E., Doukas, J. A., \& Gonenc, H. (2011). Family Control and Financing Decisions. European Financial Management, 17(5), 860-897. https://doi.org/10.1111/j.1468-036X.2011.00631.x

Cruz, C., Justo, R., \& De Castro, J. O. (2012). Does family employment enhance MSEs performance? Integrating socioemotional wealth and family embeddedness perspectives. Journal of Business Venturing, 27(1), 62-76. https://doi.org/10.1016/j.jbusvent.2010.07.002

D'Amato, A. (2020). Capital structure, debt maturity, and financial crisis: Empirical evidence from SMEs. Small Business Economics, 55, 919-941. https://doi.org/10.1007/s11187-019-00165-6

Dang, V. A. (2013). An empirical analysis of zero-leverage firms: New evidence from the UK. International Review of Financial Analysis, 30(5), 189-202. https://doi.org/10.1016/j.irfa.2013.08.007

Daskalakis, N., \& Psillaki, M. (2008). Do country or firm factors explain capital structure? Evidence from SMEs in France and Greece. Applied Financial Economics, 18(2), 87-97. https://doi.org/10.1080/09603100601018864

Daskalakis, N., Balios, D., \& Dalla, V. (2017). The behaviour of SMEs' capital structure determinants in different macroeconomic states. Journal of Corporate Finance, 46, 248-260. https://doi.org/10.1016/j.jcorpfin.2017.07.005

Datta, S., Iskandar-Datta, M., \& Raman, K. (2005). Managerial Stock Ownership and the Maturity Structure of Corporate Debt. Journal of Finance, 55(5), 2333-2350. https://doi.org/10.1111/j.1540-6261.2005.00800.x

De Massis, A., Frattini, F., Antonio, M. A., \& Piscitello, L. (2018). Family firms in the global economy: Toward a deeper understanding of internationalization determinants, processes, and outcomes. Global Strategy Journal, 8, 3-21. https://doi.org/10.1002/gsj.1199

DeAngelo, H., \& DeAngelo, L. (2007). Capital structure, payout policy and financial flexibility. Marshall School of Business, Working Paper No. FBE 02-06. Retrieved from https://papers.ssrn.com/sol3/papers.cfm?abstract_id=916093

DeAngelo, H., \& Masulis. R. (1980). Optimal Capital Structure Under Corporate and Personal Taxation. Journal of Financial Economics, 8, 3-29. https://doi.org/10.1016/0304-405X(80)90019-7

Demirgüç-Kunt, A., Martinez, P. M. S., \& Tressel, T. (2020). The global financial crisis and the capital structure of firms: Was the impact more severe among SME sand non-listed firms? Journal of Corporate Finance, 60(C), 1-32. https://doi.org/10.1016/j.jcorpfin.2019.101514

Detienne, D. R., \& Chirico, F. (2013). Exit strategies in family firms: How socioemotional wealth drives the threshold of performance. Entrepreneurship: Theory and Practice, 37(6), 1297-1318. https://doi.org/10.1111/etap.12067 
Diamond, D. W. (1991). Debt maturity structure and liquidity risk. Quarterly Journal of Economics, 106(3), 709-737. https://doi.org/10.2307/2937924

Díaz-Díaz, N. L., García-Teruel, P. J., \& Martínez-Solano, P. (2016). Debt maturity structure in private firms: Does the family control matter? Journal of Corporate Finance, 37, 393-411. https://doi.org/10.1016/j.jcorpfin.2016.01.016

Domenichelli, O. (2015). An Empirical Investigation of the Debt Maturity of Italian Family Firms. International Journal of Finance and Accounting, 4(5), 281-292. https://doi:10.5923/j.ijfa.20150405.06

Domenichelli, O. (2020). Sovereign debt crisis and capital structure decisions of firms in GIPSI countries. African Journal of Business Management, 14(10), 313-323. https://doi.org/10.5897/AJBM2020.9076

Family Firm Institute. (2017). Global data points. Retrieved from http://www.ffi.org/page/globaldatapoints.

Farhi, E., \& Tirole, J. (2018). Deadly embrace: Sovereign and financial balance sheets doom loops. Review of Economic Studies, 85(3), 1781-1823. https://doi.org/10.1093/restud/rdx059

Ferrão, J., Curto, J. D., \& Gama, A. P. (2016). Low-leverage policy dynamics: An empirical analysis. Review of Accounting and Finance, 15(4), 463-483. https://doi.org/10.1108/RAF-09-2015-0135

Flannery, M. J. (1986). Asymmetric information and risky debt maturity choice. Journal of Finance, 41(1), 19-37. https://doi.org/10.1111/j.1540-6261.1986.tb04489.x

García-Teruel, P. J., \& Martínez-Solano, P. (2007). Short-term debt in Spanish SMEs. International Small Business Journal, 25(6), 579-602. https://doi.org/10.1177/0266242607082523

Gómez-Mejia, L. R., Takacs-Haynes, K., Nuñez-Nickel, M., Jacobson, K. J. L., \& Moyano-Fuentes, J. (2007). Socioemotional wealth and business risks in family-controlled firms: Evidence from Spanish olive oil mills. Administrative Science Quarterly, 52(1), 106-137. https://doi.org/10.2189/asqu.52.1.106

Guedes, J., \& Opler, T. (1996). The determinants of the maturity of corporate debt issues. Journal of Finance, 51(5), 1809-1833. https://doi.org/10.1111/j.1540-6261.1996.tb05227.x

Habbershon, T. G., \& Williams, M. L. (1999). A Resource-Based Framework for Assessing the Strategic Advantages of Family Firms. Family Business Review 12(1), 1-25. https://doi.org/10.1111/j.1741-6248.1999.00001.x

Hauck, J., \& Prügl, R. (2015). Innovation activities during intra-family leadership succession in family firms: An empirical study from a socioemotional wealth perspective. Journal of Family Business Strategy, 6(2), 104-118. https://doi.org/10.1016/j.jfbs.2014.11.002

Hernando, I., \& Villanueva, E. (2014). The recent slowdown in bank lending in Spain: are supply-side factors relevant?. SERIEs, 5, 245-285. https://doi.org/10.1007/s13209-014-0117-7

Kale, J. R., \& Noe, T. H. (1990). Risky debt maturity choice in a sequential game equilibrium. Journal of Financial Research, 13(2), 155-166. https://doi.org/10.1111/j.1475-6803.1990.tb00545.x

Kirch, G., \& Terra, P. R. S. (2012). Determinants of corporate debt maturity in South America: Do institutional quality and financial development matter? Journal of Corporate Finance, 18(4), 980-993. https://doi.org/10.1016/j.jcorpfin.2012.05.004

Klein, S. B. (2000). Family Businesses in Germany: Significance and Structure. Family Business Review, 13(3), 157-182. https://doi.org/10.1111/j.1741-6248.2000.00157.x

Kraus, A., \& Litzenberger, R. H. (1973). A State-preference Model of Optimal Financial Leverage. Journal of Finance, 28(4), 911-922. https://doi.org/10.2307/2978343

Le Breton-Miller, I., \& Miller, D. (2013). Socioemotional Wealth Across the Family Firm Life Cycle: A Commentary on "Family Business Survival and the Role of Boards". Entrepreneurship Theory and Practice, 37(6), 1391-1397. https://doi.org/10.1111\%2Fetap.12072

Lewis, C. M. (1990). A Multiperiod Theory of Corporate Financial Policy under taxation. Journal of Financial and Quantitative Analysis, 25(1), 25-43. https://doi.org/10.2307/2330886

López-Gracia, J., \& Mestre-Barberá, R. (2011). Tax effect on Spanish SME optimum debt maturity structure. Journal of Business Research, 64(6), 649-655. https://doi.org/10.1016/j.jbusres.2010.06.001

Lòpez-Gracia, J., \& Sànchez-Andùliar, S. (2007). Financial Structure of the Family Business: Evidence from a Group of Small Spanish Firms. Family Business Review, 20(1), 269-287. 
https://doi.org/10.1111/j.1741-6248.2007.00094.x

López-Gracia, J., \& Sogorb-Mira, F. (2008). Testing trade-off and pecking order theories financing SMEs. Small Business Economics, 31(2), 117-136. https://doi.org/10.1007/s11187-007-9088-4

Magri, S. (2010). Debt Maturity Choice of Nonpublic Italian Firms, Journal of Money, Credit and Banking, 42(2-3), 443-463. https://doi.org/10.1111/j.1538-4616.2009.00294.x

Martínez-Romero, M. J., \& Rojo-Ramírez, A. A. (2016). SEW: Looking for a definition and controversial issues. European Journal of Family Business, 6, 1-9. https://doi.org/10.24310/ejfbejfb.v6i1.5042

Mork, R., \& Yeung, B. (2003). Agency Problems in Large Family Business Groups. Entrepreneurship Theory and Practice, 27(4), 367-382. https://doi.org/10.1111\%2F1540-8520.t01-1-00015

Morris, J. R. (1976). On Corporate Debt Maturity Strategies, Journal of Finance, 31(1), 29-37. https://doi.org/10.2307/2326392

Myers S. C. (1977). Determinants of Corporate Borrowing, Journal of Financial Economics, 5(2), 147-175. https://doi.org/10.1016/0304-405X(77)90015-0

Myers, S. C. (1984). The Capital Structure Puzzle. Journal of Finance, 39(3), 575-592. https://doi.org/10.1111/j.1540-6261.1984.tb03646.x

Myers, S. C., \& Majluf N. S. (1984). Corporate Financing and Investment Decisions When Firms Have Information That Investors Do Not Have. Journal of Financial Economics, 13(2), 187-221. https://doi.org/10.1016/0304-405X(84)90023-0

Naldi, L., Cennamo, C., Corbetta, G., \& Gomez-Mejia, L. (2013). Preserving Socioemotional Wealth in Family Firms: Asset or Liability? The Moderating Role of Business Context. Entrepreneurship Theory and Practice, 37(6), 1341-1360. https://doi.org/10.1111\%2Fetap.12069

Ozkan, A. (2000). An empirical analysis of corporate debt maturity structure. European Financial Management, 6(2), 197-212. https://doi.org/10.1111/1468-036X.00120

Ozkan, A. (2002). The determinants of corporate debt maturity: Evidence from UK firms. Applied Financial Economics, 12(1), 19-24. https://doi.org/10.1080/09603100110102691

PricewaterhouseCoopers. (2007). The PricewaterhouseCoopers Family Business Survey 2007/08. Retrieved from https://www.pwc.co.za/en/assets/pdf/pwc-family-business-survey-08.pdf

Rajan, R., \& Winton, A. (1995). Covenants and Collateral as Incentives to Monitor. Journal of Finance, 50(4), 1113-1146. https://doi.org/10.1111/j.1540-6261.1995.tb04052.x

Ravid, A. (1996). Debt Maturity - A survey. Financial Markets, Institutions \& Instruments, 5(3), 1-69.

Scherr, F., \& Hulburt, H. M. (2001). The Debt Maturity Structure of Small Firms. Financial Management, 30(1), 85-111.

Sciascia, S., Mazzola, P., \& Kellermanns, F. W. (2014), Family management and profitability in private family-owned firms: Introducing generational stage and the socioemotional wealth perspective. Journal of Family Business Strategy, 5(2), 131-137. https://doi.org/10.1016/j.jfbs.2014.03.001

Sharma, P. (2002). Stakeholder mapping technique: toward the development of a family firm typology. Paper presented at the Academy of Management meetings, Denver, CO. Retrieved from https://www.researchgate.net/publication/237135059_Stakeholder_Mapping_Technique_Toward_the_Devel opment_of_a_Family_Firm_Typology

Sharma, P. (2004). An Overview of the Field of Family Business Studies: Current Status and Directions for the Future. Family Business Review, 17(1), 1-36. https://doi.org/10.1111\%2Fj.1741-6248.2004.00001.x

Shyu, Y. W., \& Lee, C. I. (2009). Excess Control Rights and Debt Maturity Structure in Family-Controlled Firms. Corporate Governance: An International Review, 17(5), 611-628. https://doi.org/10.1111/j.1467-8683.2009.00755.x

Stephan, A., Talavera, O., \& Andriy, T. (2011). Corporate debt maturity choice in emerging financial markets. Quarterly Review of Economics and Finance, 51(2), 141-151. https://doi.org/10.1016/j.qref.2010.12.003

Stockmans, A., Lybaert, N., \& Voordeckers, W. (2010). Socioemotional Wealth and earnings management in private family firms. Family Business Review, 23(3), 280-294. https://doi.org/10.1177\%2F0894486510374457 
Stohs, M. H., \& Mauer, D. C. (1996). The Determinants of Corporate Debt Maturity Structure. Journal of Business, 69(3), 279-312. http://dx.doi.org/10.1086/209692

Straska, M., \& Waller, H. G. (2014) Antitakeover Provisions and Shareholder Wealth: A Survey of the Literature. Journal of Financial and Quantitative Analysis, 49(4), 933-956. https://doi.org/10.1017/S0022109014000532

Titman, S., \& Wessels, R. (1988). The Determinants of Capital Structure Choice. The Journal of Finance, 43(1), 1-19. https://doi.org/10.1111/j.1540-6261.1988.tb02585.x

Tsang, E. W. K. (2002). Learning from overseas venturing experience. The case of Chinese family businesses. Journal of Business Venturing, 17, 21-40. https://doi.org/10.1016/S0883-9026(00)00052-5

Vandekerkhof, P., Steijvers, T., Hendriks, W., \& Voordeckers, W. (2015). The effect of organizational characteristics on the appointment of nonfamily managers in private family firms: The moderating role of Socioemotional Wealth. Family Business Review, 28(2), 104-122. https://doi.org/10.1177\%2F0894486513514274

Villalonga, B., \& Amit, R. (2010). Family Control of Firms and Industries. Financial Management, 39(3), 863-904. https://doi.org/10.1111/j.1755-053X.2010.01098.x

Villalonga, B., Amit, R., Trujillo, M. A., \& Guzmán, A. (2015). Governance of Family Firms. Annual Review of Financial Economics, 7, 635-654. https://doi.org/10.1146/annurev-financial-110613-034357

Zellweger, T. M., \& Astrachan, J. H. (2008). On the Emotional Value of Owning a Firm. Family Business Review, 2l(3), 347-363. https://doi.org/10.1177\%2F08944865080210040106

Zellweger, T. M., \& Dehlen, T. (2011) Value is in the eye of the owner: Affect infusion and Socioemotional Wealth among family firm owners. Family Business Review, 25(3), 280-297. https://doi.org/10.1177\%2F0894486511416648

Zellweger, T. M., Kellermanns, F. W., Chrisman, J. J., \& Chua, J. H. (2012). Family control and family firm valuation by family CEOs: The importance of intentions for transgenerational control. Organization Science, 23(3), 851-868. https://doi.org/10.1287/orsc.1110.0665

Zellweger, T. M., Nason, R. S., Nordqvist, M., \& Brush, C. G. (2013). Why Do Family Firms Strive for Nonfinancial Goals? An Organizational Identity Perspective. Entrepreneurship Theory and Practice, 37(2), 229-248. https://doi.org/10.1111/j.1540-6520.2011.00466.x

\section{Notes}

Note 1. For a thorough survey of the theoretical and empirical studies on the maturity structure of corporate debt, see Ravid (1996).

Note 2. By definition a private firm is a firm which is not listed and thus with no access to financial markets.

\section{Copyrights}

Copyright for this article is retained by the author(s), with first publication rights granted to the journal.

This is an open-access article distributed under the terms and conditions of the Creative Commons Attribution license (http://creativecommons.org/licenses/by/4.0/). 